\title{
THE NEED FOR CHANGE IN THE APPROACH TO INSOLVENCY OF SPORT CLUBS IN THE REGULATIONS OF THE EUROPEAN FOOTBALL FEDERATION
}

\author{
Rafal ADAMUS \\ E-mail: radamus@uni.opole.pl; adamus_rafal@wp.pl \\ prof. UO dr hab. \\ University of Opole (Poland) \\ Institute of Legal Sciences UO \\ Department of Commercial and Financial Law
}

\begin{abstract}
This study concerns the issues of league regulations related to the legal problem of insolvency of football clubs in the context of licenses to participate in competitions. The study presents a brief description of modern European football, including the phenomenon of financial oligarchization of sport, and uneven redistribution of the benefits of sport. The following section presents the relation between lex sportiva and state law; the legal position and importance of UEFA; licensing system rules for participating in games. Particular attention was paid to regulating the impact of participation in proceedings giving protection against creditors on obtaining and maintaining a license. Attributes of proceedings in case of threat of insolvency and insolvency are presented as well. Finally, there is presented an example of national regulation which is in force in Poland (a Member State of the European Union). The final conclusion is a recommendation for a strategic change in the licensing system's approach to the problem of proceedings giving protection against creditors.
\end{abstract}

Key words: UEFA, football club, license, bankruptcy, restructuring, lex sportiva

\section{INTRODUCTION}

This study is devoted to the need for change in the approach to phenomena of insolvency of a sports club in the regulations (lex sportiva) of UEFA - Union of European Football Associations. The study will present a brief description of contemporary football problems in Europe and a short list of the 
characteristics of UEFA. In addition, the conditions of the licensing system allowing football clubs to participate in national league and on European level will be presented, one of which is adequate financial liquidity of a football club. In other words, bankruptcy of a sport club results in the inability to obtain a license. The lex sportiva regulation in this respect does not seem to be very flexible due to the possibilities arising from the modern regulation of bankruptcy and restructuring law of the countries in which the clubs are incorporated. Finally, because an annual license for a football club is given on the national level and there are strong links between UEFA regulations and national football federation regulations, an analysis will be presented of the national league's approach to bankruptcy in the one selected European country (Poland) where the UEFA member is based. The presented issue takes on special significance in the context of the economic crisis resulting from the COVID-19 pandemic.

\section{THE LANDSCAPE OF THE EUROPEAN FOOTBALL}

What is the present landscape of the European football? European football is creating a number of positive social phenomena such as promotion of sport and physical culture, activation of economic development related to sport, etc. Nevertheless, in this study the adverse effects will be highlighted.

Europe professional football is a commercialized enterprise. In practice, European football is an oligopoly in that the richest football clubs very often enjoy the bottomless funds of their owners. There is a strong, albeit not exclusive, relationship between sports achievements and club budget. The richest football clubs can buy the best players, usually the most expensive, and employ the best coaches. Poor football clubs cannot afford to compete in the market of top- earning football stars, so they have worse, less talented players. In 2009 UEFA established Financial Fair Play Regulations (which were periodically updated in $2012,2015,2018$ ) to prevent professional football clubs from spending more money than they earn in the pursuit of success. Such risky practices drived clubs into financial problems which might threaten their long-term survival. However they solve only some of the problems that arise. Simply they do not eliminate the phenomenon of "oligarchization" of sport. In 2020 UEFA punished Manchester City F.C. two years of exclusion from the game in European cups and a financial penalty of EUR 30 million. According to UEFA, the reason for this penalty was a violation of the Financial Fair Play Rules. The club assessed the accusations against Manchester City F.C. as untrue. Owner of Manchester City F.C. is Sheikh Mansosur bin Zayed Al Nahyan. UEFA reservations concerned, among others the fact that in 2012-2016 the club was to receive a sum of 51.5 million pounds based on sponsorship agreements not from the sponsor in the person of Etihad Airways but from a formally other entity of the club owner 
The need for change in the approach to insolvency of sport clubs...

Abu Dhabi United. Interestingly, football is not a sport in which the United Arab Emirates specialize. According to the prestigious World Football Elo Ratings, this country is classified in 94 position.

In terms of financial size, European football is dominated by five leagues from major European countries: the English "Premier League", the Spanish "La Liga", the German "Bundesliga", the Italian "Serie A" and the French "Ligue 1". About 100 European clubs achieve revenues at over 50 million euros per yearand approximately $90 \%$ of these tycoons belong to the Big Five. In the UEFA Champions League (the most popular European competitions of the best football clubs), in the last decade only six teams reached the trophy: Real Madrid (2014, 2016, 2017, 2018), FC Barcelona (2011, 2015), Liverpool FC (2019), Chelsea FC (2012), Bayern Munich (2013), Inter Milan (2010). Bayern Munich (2010, 2012), Borussia Dortmund (2013), Manchester United (2011), Atletico Madrid (2014, 2016), Juventus FC (2015, 2017), Liverpool FC (2018), Tottenham Hotspur (2019) also reached the final level. The oligopoly of the richest clubs settled permanently in the forefront of Europe's club football (Adamus R 2019, p. 20). It resembles the Byzantine succession to the throne within the ruling family.

The family of the richest football clubs in Europe include Real Madrid, FC Barcelona, Manchester United, Bayern Munich. Real Madrid's revenue in 2019: $€ 750.9$ million ( $£ 665.2$ million or $\$ 847.7$ million). Previous revenue: $€ 674.6$ million. FC Barcelona’s revenue in 2019: €690.4 million (£611.6 million or $\$ 779.4$ million). Previous revenue: $€ 648.3$ million. Manchester United' s revenue in 2019: $€ 666$ million ( $£ 590$ million or $\$ 751.8$ million), Previous revenue: $€ 676.3$ million. Bayern Munich’s revenue in 2019: €629.2 million (£557.4 million or \$710.3 million). Previous Revenue: $€ 587.8$ million. (https://sportsshow.net/richest-football-clubs/). Real Madrid won the national championship 33 times (twice in last decade), took second place 23 times and third place 10 times. In the same league, FC Barcelona was first 26 times (including 7 times in the last decade),second 25 times and third 12 times. Bayern Munich won the Bundesliga 29 times (including eight times in the last decade), was second 10 times and third five times. These data show a significant relationship between big money invested in football and sports results. Only strong clubs can count in European competitions, therefore the stronger the club in the national league, the greater its chance for European trophies.

The history of modern football begins in England. The first rules of the game were written at Sheffield in 1857 and at Cambridge in 1858. In 1882, at Manchester, British football associations set up the International Football Association Board, an organization to set football rules. Football was not born as an elite sport. On the contrary, it was mainly entertainment for workers. In the last three decades the English league, thanks to the negotiation of TV stations broadcasting football matches, moved from poor stadiums (often with wooden stands and standing places for fans) and football pitches(in 1985, 32 
people died at Heysel stadium, and in 1989, as many as 96 people were killed at the Hillsborough stadium). Professional football in England has become an investment plot for North American business, Russian oligarchs, and Arab sheikhs. Investing in football is often guided by marketing goals located outside of sport. A sports club can serve well as a validating instrument in other powerful business ventures. There are also far-reaching social consequences of the lucrative contracts between English football clubs and television stations. Football matches are broadcasts only available on pay TV. Fees for sports channels also introduce a property census for less affluent local supporters. However, broadcasts of Premier League matches are available for a fee in almost all countries of the world. From a purely economic point of view, subscribers do not have to be local. Football in England is breaking away from its roots and local traditions and becoming more elite (Adamus R (21-27.10.2019), p. 88 -89).

Large budgets of some sports clubs are, however, a very negative phenomenon in the long run. With an extremely high income, the spirit of sport easily loses to the interest of mammon and economic calculation. The oligopoly of rich clubs reserves the most talented players for themselves. Poor clubs can only afford average players. This leads to sport disparities. Moreover, higher and higher costs of football activity create a serious risk of insolvency for many football clubs.

European football players' earnings, despite their dizzying levels, continue to show an upward trend (in the days before the COVID -19 pandemic). Professional kicking is not only a sporting competition but also a lucrative business. Is there an absolute limit for the top earnings of top players? In the business of football, the usual rules of supply and demand apply. Players earn so much because the leading football clubs are ready to spend so much money on their salaries and transfer fees. Football clubs have huge budgets built in large part from revenues from television broadcasts. But is not this the mythical Uroboros, a snake slowly devouring its own tail? In the never ending race for higher costs of employing footballers, the phenomenon of impoverishment of poorer clubs raises the risk of insolvency of football clubs.

\section{LEX SPORTIVA}

Many aspects of football activity are not regulated by the state law. There are rather "private" regulations of sports law. The term "lex sportiva" ("sports law") is commonly used by the doctrine of law (Siekmann R.C.R. Soek J 2012 p. 12, Siekmann R.C.R. 2012p. 12, James M 2013 p. 10, Blackshaw I S 2017 p. 8, Gardiner S 2001 p. 7, Greenfield S Osborn G 2000 p. 5, Widłak T 2015 p. 81). This doctrine is assigned various ranges of meaning. In one of the broader meaning the term "lex sportiva" covers all the law and case law from non-governmental sports organizations and institutions operating in international (or supranational) space. However, the emphasis is on the special importance of separate sports principles (principia sportiva) and emerging 
The need for change in the approach to insolvency of sport clubs...

original doctrinal concepts (Widłak T, 2015 p. 84). Regulation of sport matters enjoys considerable autonomy (Wiktorowski D 2015 p. VIII, Chołub A 2015 p. IV, Kulikowska M 2015 p. XXXIII). A part of lex ludica are "fair play" rules. Under UEFA Statutes Rules of Procedure of the UEFA Congress Regulations governing the Implementation of the UEFA Statutes April 2017 edition, "fair play means acting according to ethical principles which, in particular, oppose the concept of sporting success at any price, promote integrity and equal opportunities for all competitors, and emphasize respect of the personality and worth of everyone involved in a sporting event".

For example, the Laws of the Game are decided by the International Football Association Board (IFAB). Article $7 \mathrm{sec}$. 1. FIFA Statutes Regulation Governing the Application of the Statutes

Standing Orders of the Congress August 2018 edition (hereafter "FIFA Stat.") states that each member association of FIFA shall play association football in compliance with the Laws of the Game issued by the IFAB. Only the IFAB may lay down and alter the Laws of the Game.

Bankruptcy and restructuring law remains within the legislative powers of the state in which the football club is located. Nevertheless, lex sportiva sets out certain consequences of the club's insolvency for participation in the competition.

\section{THE POSITION OF UEFA IN THE EUROPEAN FOOTBALL}

The most important football organization on the European level is the "Union des Associations Européennes de Football" (UEFA). As one of six continental confederations of "Fédération Internationale de Football Association" (FIFA), world football's governing body, UEFA takes part in setting lex sportiva. The Fédération Internationale de Football Association (FIFA) is an association registered in the Commercial Register of the Canton of Zurich in accordance with Article 60 of the Swiss Civil Code (Article 1 sec. 1 FIFA Stat.). National, member associations that belong to the same continent have formed the following confederations, which are recognized by FIFA: (a) "Confederación Sudamericana de Fútbol" - CONMEBOL (b) "Asian Football Confederation" - AFC (c) "Union des associations européennes de football" - UEFA (d) "Confédération Africaine de Football" CAF (e) "Confederation of North, Central America and Caribbean Association Football" - CONCACAF (f) "Oceania Football Confederation" OFC (Article 22 sec. 1 FIFA Stat.).

UEFA is a confederation recognized by FIFA (Article 3 sec. 1 UEFA Stat.). UEFA has the sole jurisdiction to organize or abolish international football competitions in Europe in which national member associations and their clubs participate. The current UEFA competitions for national representative teams 
include UEFA European Football Championship ${ }^{1}$ and, for club teams, UEFA Champions League and UEFA Europa League ${ }^{2}$ (Article 49 sec. 1,2 UEFA Stat). UEFA controls lucrative media rights to those competitions.

The objectives of UEFA are to "deal with all questions relating to European football", "promote football in Europe in a spirit of peace, understanding and fair play, without any discrimination on account of politics, gender, religion, race or any other reason" and "act as a representative voice for the European football family as a whole" (Article 2 sec. 1 a, b, 1 UEFA Stat).

It should be underlined that UEFA is in a position to "promote and protect ethical standards and good governance in European football", "ensure that sporting values always prevail over commercial interests" and "redistribute revenue generated by football in accordance with the principle of solidarity and to support reinvestment in favor of all levels and areas of football, especially the grassroots of the game" (Article 2 sec. $1 \mathrm{f}, \mathrm{g}, \mathrm{h}$ UEFA Stat).

UEFA, in order to exercise its competences, is entitled to implement any measures it deems appropriate, such as setting down rules, entering into agreements or conventions, taking decisions or adopting programs (Article 2 sec. 2 UEFA Stat). It is very important that UEFA is in a position to impose disciplinary measures for unsportsmanlike conduct, violations of the Laws of the Game, and contravention of UEFA's Statutes, regulations, decisions and directives (Article 52 UEFA Stat).There are many various disciplinary measures which may be imposed against member associations and football clubs: a) a warning, b) a reprimand, c) a fine, d) the annulment of the result of a match, e) an order that a match be replayed, f) the deduction of points, g) awarding a match by default, h) staging of matches behind closed doors, i) ordering a ban on the use of a stadium, $\mathrm{j}$ ) ordering the playing of a match in a third country, k) the withholding of revenues from a UEFA competition, l) the prohibition on registering new players in UEFA competitions, $\mathrm{m}$ ) a restriction on the number of players that a club may register for participation in UEFA competitions, n) disqualification from competitions in progress and/or exclusion from future competitions, o) the withdrawal of a title or award, p) the withdrawal of a license (Article $53 \mathrm{sec}$. 1 UEFA Stat.). There is no numerus clauses of disciplinary measures because further disciplinary measures against Member Associations and clubs may be defined in regulations adopted by the Executive Committee (Article $53 \mathrm{sec}$. 2 UEFA

\footnotetext{
${ }^{1}$ UEFA European Under-21 Championship, UEFA European Under-19 Championship, UEFA European Under-17 Championship, UEFA European Women's Championship, UEFA European Women's Under-19 Championship, UEFA European Women's Under-17 Championship, UEFA European Futsal Championship - UEFA Regions' Cup Club Teams

${ }^{2}$ UEFA Super Cup, UEFA Futsal Cup, UEFA Women's Champions League
} 
The need for change in the approach to insolvency of sport clubs...

Stat). Therefore, UEFA's competences include ensuring stable football development. To this purpose, it may undertake regulatory activities binding to national federations and football clubs.

However, UEFA being a football governing body at the European level is not a public law entity but is a private association entered in the register of companies in Switzerland under the terms of Article 60 of Swiss Civil Code (Article 1 sec. 1 UEFA Stat). The Statutes of UEFA is governed in all respects by Swiss law. The legal forum is Lausanne in Switzerland (Article 64 UEFA Stat.). Under Article $63 \mathrm{sec}$. 1 of the Swiss Civil Code where the articles of association do not provide rules for the association's organization or its relationship with its members, the provisions of Swiss Civil Code apply. In turn Article $63 \mathrm{sec} .2$ of the Swiss Civil Code provides that mandatory provisions of law (ius cogens) cannot be altered by the articles of association. Article $60 \mathrm{sec} .1$ of the Swiss Civil Code stipulates that associations with a political, religious, scientific, cultural, charitable, social or other noncommercial purpose acquire legal personality as soon as their intention to exist as a corporate body is apparent from their articles of association.

UEFA consists of 55 national association members. Membership of UEFA is open to national football associations situated in Europe, which are responsible for the organization and implementation of football-related matters in the territory of their country (Article 5 sec. 1 UEFA Stat). In exceptional circumstances, a national football association that is situated in another continent may be admitted to membership, provided that it is not a member of the confederation of that continent, or of any other confederation, and that FIFA approves its membership of UEFA (Article $5 \mathrm{sec}$. 2 UEFA Stat). Several members of UEFA are from states which are primarily or entirely located in Asia.

UEFA prepared regulations governing the conditions of participation in and the staging of UEFA competitions. UEFA defined a special club licensing system including, in particular, the minimum criteria to be fulfilled by clubs in order to be admitted to UEFA competitions; the licensing process; the minimum requirements to be observed by the licensors (Article $50 \mathrm{sec}$. 1 UEFA Stat).

\section{UEFA LICENSING SYSTEM}

UEFA Club Licensing and Financial Fair Play Regulations (hereafter UEFA Reg)

govern the rights, duties and responsibilities of all parties involved in the UEFA club licensing system and define in particular: a) the minimum requirements to be fulfilled by a UEFA member association 
in order to act as the licensor for its clubs, as well as the minimum procedures to be followed by the licensor in its assessment of the club licensing criteria; b) the license applicant and the license required to enter the UEFA club competitions; c) the minimum sporting, infrastructure, personnel and administrative, legal and financial criteria to be fulfilled by a club in order to be granted a license by its licensor as part of the admission procedure to enter the UEFA club competitions

(Article 1 sec. 2 UEFA Reg.).

The UEFA regulations aim to achieve maximum level of "financial fair play" in UEFA football club competitions. They are created in order to improve the economic and financial capability of the football clubs, increasing their financial transparency and credibility (Article 2 sec. 2a, UEFA Reg). UEFA stresses the necessary importance of the protection of creditors of the football clubs. The clubs should settle their liabilities with employees (players), social and tax authorities and other clubs in due time (Article 2 sec. $2 b$, UEFA Reg.). UEFA intends to provide "more discipline and rationality" in club finances (Article $2 \mathrm{sec}$. 2c, UEFA Reg) It is a very important factor in opposing the madness of top football players' wages. UEFA aims "to encourage clubs to operate on the basis of their own revenues" (Article $2 \mathrm{sec}$. 2d, UEFA Reg.). Finally, UEFA aims to "encourage responsible spending for the long-term benefit of football" (Article 2 sec. 2e, UEFA Reg) and "to protect the long-term viability and sustainability of European club football" (Article 2 sec. 2f, UEFA Reg).

Aclub's financial standing is of key importance in terms of allowing the club to participate in the competition at the national and European level. Under UEFA regulation, the license applicant must prove that as of 31 March preceding the license season it has no:

1. overdue payables ${ }^{3}$ towards other football clubs as a result of transfers undertaken prior to the previous 31 December;

2. overdue payables ${ }^{4}$ in respect of its employees as a result of contractual or legal obligations that arose prior to the previous 31 December;

\footnotetext{
3"Payables" are amounts due to football clubs as a result of transfer activities, including any amount due upon fulfillment of certain conditions; training compensation and solidarity contributions as defined in the FIFA Regulations on the Status and Transfer of Players.

4 "Payables" are all forms of consideration due in respect of employees as a result of contractual or legal obligations, including wages, salaries, image rights payments, bonuses and other benefits. Amounts payable to people who, for various reasons, are no longer employed by the applicant fall within the
} 
The need for change in the approach to insolvency of sport clubs...

3. overdue payables towards social and tax authorities as a result of contractual or legal obligations in respect of its employees that arose prior to the previous 31 December.

\section{PROTECTION FROM CREDITORS PROCEDURES AND THE UEFALICENSE SYSTEM}

An important assumption made in UEFA regulations is the forced elimination from the football competition of clubs having serious financial problems. However, the problem of insolvency is so complex that such a singular approach is not enough.

UEFA Regulations use the term "protection from creditors" with the following meaning: "procedures pursuant to laws or regulations whose objectives are to protect an entity from creditors, rescue insolvent entities and allow them to carry on running their business as a going concern. This process encompasses administration procedures and other insolvency proceedings (that might result in a compromise with creditors, bankruptcy or liquidation)".Annex IX of the UEFA Reg. Those proceedings are stipulated by state law.

In the Licensor's assessment procedures of Annex IX of the UEFA Reg, it is stipulated that if "the license applicant or any parent company of the license applicant included in the reporting perimeter is or was seeking protection or has received or is still receiving protection from its creditors pursuant to laws or regulations within the 12 months preceding the license season then the license must be refused". In order to avoid any doubt the license must also be refused even if the concerned entity is no longer receiving protection from its creditors at the moment the licensing decision is taken.

The "Calculation of the break-even result section of Annex X of the UEFA Reg" states that relevant income must be decreased in case of credit in respect of a reduction of liabilities arising from procedures providing protection from creditors. Any credit in respect of a reduction of liabilities arising from procedures providing protection from creditors must be excluded from the calculation of the break-even result.

scope of this criterion and must be settled within the period stipulated in the contract and/or defined by law, regardless of how such payables are accounted for in the financial statements. The term "employees" includes the following persons: all professional players according to the applicable FIFA Regulations on the Status and Transfer of Players and the administrative, technical, medical and security staff as well. 


\section{BANKRUPTCY AND RESTRUCTURING PROCEEDINGS AS THE REMEDY FOR FOOTBALL CLUBS FINANCIAL PROBLEMS}

UEFA can reduce the risk of insolvency of football clubs by setting sustainable and proportional spending limits. In particular, less wealthy clubs should avoid overinvestment. The common reasons for the insolvency of many sports clubs are too high costs related to salaries for players, transfer fees, etc. The largest part of football clubs' budgets is spent on remuneration for footballers. The question arises whether or not UEFA, using its powers, should set flexible salary limits and transfer limits. The unrestrained increase in players' remuneration has a number of adverse consequences. There is a strong temptation for football clubs to balance expenses from future profits depending on sports achievements. However accurate prediction of sports results is not possible. Expenditure limits can eliminate socially dangerous gambling strategies of football clubs and help to avoid their insolvency. The COVID -19 pandemic has shown that any major disruption to the club's revenue structure results in difficulties in paying such high wages. High football salary costs limit clubs' spending on social goals in the local environment, including investing in universal training for young people (not only talented ones). Clubs which are forced to search for sources of financing salaries increase the costs of "supporting" for football fans. The prices of tickets and club gadgets are rising. Match broadcasts are only available in paid versions. Limits should not be a punishment for wealth or a limiter for the development of ambitious clubs. Nevertheless, a balanced regulatory policy seems to be needed.

There is, however, a serious legal dilemma if it is permissible to limit contractual freedom of autonomous civil law entities. Nevertheless, it can be argued that for the purpose of participation in a sporting venture, a limitation on the funds to be allocated for player remuneration is allowable. Under lex sportiva it is possible to stipulate a sanction in the form of, for example, deduction of points for violation of limits. Professional football is subject to typical business rules. Some analogies can be seen between the activity of some football clubs and abuse of a dominant position prohibited by antitrust law. This is also an important argument for the introduction of limits. The laws of European countries in which the clubs have their seat guarantee: the principle of the autonomy of the will, the principle of freedom of contract. The economic system is based on the free market economy model. For this reason, any limits should have appropriate axiological justification. Limits (as exceptions to the freedom of contract) should comply with the principle of proportionality. Limits should be structured in a flexible way. They should not be discriminatory for any football club. They should include smaller football clubs that could overinvest in the race to recruit talented footballers. A broader analysis of the structure of limits and sanctions exceeds the 
The need for change in the approach to insolvency of sport clubs...

boundaries of this study. In summary, limits could contribute to the elimination of many insolvency accidents for football clubs.

Expenditure limits should not violate the principles of public competition protection law. Judgement of the Court of Justice (Third Chamber) on 18 July 2006 in Case C-519/04 P, appeal under Article 56 of the Statute of the Court of Justice lodged on 22 December 2004, David Meca-Medina, residing in Barcelona (Spain), Igor Majcen, residing in Ljubljana (Slovenia), stipulates that:

therefore, even if the anti-doping rules at issue are to be regarded as a decision of an association of undertakings limiting the appellants' freedom of action, they do not, for all that, necessarily constitute a restriction of competition incompatible with the common market, within the meaning of Article $81 \mathrm{EC}$, since they are justified by a legitimate objective. Such a limitation is inherent in the organisation and proper conduct of competitive sport and its very purpose is to ensure healthy rivalry between athletes.

The issue of the relationship between competition law and expenditure limits would require a separate study. Nevertheless, in the USA, the system of spending limits on players (,salary cap”. „wage cap”) does not violate the competition law.

Further, it can be argued that UEFA represents, in given regulations, an outdated approach to the institution of insolvency and bankruptcy. UNCITRAL (United Nation Commission on International Trade Law) Legislative Guide on Insolvency Law stipulates that "when a debtor is unable to pay its debts and other liabilities as they become due, most legal systems provide a legal mechanism to address the collective satisfaction of the outstanding claims from assets (whether tangible or intangible) of the debtor" (UNCITRAL 2005, p.15).There are two main directions for dealing with insolvent debtors. Either compulsory liquidation of the debtor's assets or the conclusion of an arrangement between the debtor and creditors. However, as part of the liquidation of the debtor's assets, the investor may take over such assets so the investor may continue the business previously carried out by the debtor.

Sports law cannot change or replace the rules of state insolvency law. Nevertheless, to the extent that insolvency law leaves the participants of proceedings free to decide, sports law may determine under what conditions insolvency law institutions may be used by football clubs. In particular, the procedure involving the arrangement between the debtor and creditors most often leaves a large margin of discretion when constructing the arrangement. 
It should be mentioned that the Directive (EU) 2019/1023 of the European Parliament and of the Council of 20 June 2019 on preventive restructuring frameworks, on discharge of debt and disqualifications, and on measures to increase the efficiency of procedures concerning restructuring, insolvency and discharge of debt, and amending Directive (EU) 2017/1132 (Directive on restructuring and insolvency)insists on the benefits of restructuring liabilities, including at an earlier stage of insolvency risk. In the preamble of the Directive it is stipulated that "restructuring should enable debtors in financial difficulties to continue business, in whole or in part, by changing the composition, conditions or structure of their assets and their liabilities or any other part of their capital structure - including by sales of assets or parts of the business or, where so provided under national law, the business as a whole - as well as by carrying out operational changes".

Bankruptcy, as a general execution, is the best way to protect the interests of all creditors of an insolvent debtor and in this space the regulation of league law cannot compete with generally applicable state law. The fear of being excluded from the competition may prevent the sports club board from submitting a usually obligatory bankruptcy petition. Thus, the inflexible regulation of the lex sportiva may lead to some side effects contrary to the axiology of the licensing system: the lack of timely application for bankruptcy of the sports club will work against its creditors. It seems that it is possible to reconcile the legal and economic security of the creditors of the insolvent sports company and to ensure the continuity of sports games.

In what direction should the changes in the club's insolvency approach go?

1. De lege ferenda (as a postulate of changes in law): Opening a restructuring procedure of a sports club, the statutory effect of which is to suspend payment of arrangement obligations, should not have a negative impact on the license. Opening such a procedure should not automatically deprive a club of a license. It may, however, lead to an inspection procedure regarding club finances. It should be stipulated expresiss verbis. Opening of restructuring proceedings does not prejudge the dissatisfaction of creditors.

2. Moreover, conclusion an arrangement in a restructuring procedure in which the indebted sports club concludes an arrangement with creditors should not have a negative impact on the license. It could be required under lex sportive that the arrangement concluded by a football club should provide for full repayment to creditors such as other football clubs, employees, social and tax authorities. The arrangement may therefore provide for a grace period in the payment of obligations as well as payment in installments. A partly reduction of some claims, including in particular interest payments, may also be allowed with the express consent of a creditor (volentinon fitiniuria). 
The need for change in the approach to insolvency of sport clubs...

Another non-pecuniary formula for satisfying creditors may also be allowed with the express consent of a creditor. A conversion of receivables into shares or stocks of a sports club run in the form of a limited liability company or a joint-stock company might be allowed for example.

3. Bankruptcy is connected with the liquidation of the debtor's assets. State regulations in many cases create such a situation that the buyer of the assets of the bankrupt may continue the debtor's previous activities. In this context, the option of "transferring" the license to the buyer of the assets of the indebted football club should be introduced, or conditional licensing of the investor, or perhaps providing a promise of a license and a fast path for obtaining the license by the investor.

\section{AN EXAMPLE OF THE EUROPEAN DOMESTIC REGULATIONS}

\section{a) General remarks on Polish sports and insolvency law}

Reflections on approaches to bankruptcy at the European level will be supplemented with a brief analysis on the regulations of a selected UEFA member with its registered seat in Poland.

It should be explained that sporting activities in Poland, including football, are conducted in the form of a sports club (Article $3 \mathrm{sec} .1$ Act on June 25, 2010 on sport consolidated text Journal of Laws from 2019, item 1468, as amended). Sport, within the meaning of the Act on sport, includes all forms of physical activity that through ad hoc or organized participation affects working out or improvement physical and mental condition, development of social relations or achievement sports results at all levels. Activity-based on intellectual competition which goal is to achieve a sports result is also considered sport. The sports club in Poland operates in legal transactions as a legal entity (Article $3 \mathrm{sec}$. 2 Act on sport). It should be stressed that - in accordance with Article $15 \mathrm{sec} .3$ Act on sport - sports clubs operating in the professional league should be either a joint-stock company or a limited liability company. However, point 4.1.2.1. of the Podręcznik Licencyjny Ekstraklasy na sezon 2020/2021 i następne, ( Hereafter referred to as License Guide) states that football clubs participating in the "Ekstraklasa" games (the highest football class in Poland) must have the legal form of a joint-stock company which is the most formalized company known in Polish law. On the financing of football clubs in Poland, see for example: Kiełbasiński, W and Kosecki, M 2015, p. XL, Osiński Ł, 2017 p. XXIV, Warchoł, M (2015) p. IX.

In accordance with Act on Sport, Article $13 \mathrm{sec} .1$ point 2, the Polish sports association has the exclusive right to establish and implement sporting, organizational and disciplinary rules in the sporting competition it 
organizes(Greenfield, 2001 p. 14) (Sports rules and fair play rules in sport are referred to as lex ludica. Foster K 2006 passim). The only exception of disciplinary rules on doping in sport. It should be stressed that under Article 7 sec. 1 of the Act on Sport a sports association is created to organize and manage competition in a given sport. This is the normative basis for creating the so-called league law, a type of soft law, which is not a set of generally applicable standards. On this normative basis, among others, the License Guide is published by PZPN (Wiktorowski D 2015 Nowe przepisy licencyjne PZPN dla klubów Ekstraklasy p. IV, Bołyń M 2016 p. IV).Sports, organizational and disciplinary rules set by the Polish sports association are, within their jurisdiction, effective erga omnes (effective against everyone). The minister competent for physical culture exercises supervision over the activities of Polish sports associations (Act on Sport, Article $16 \mathrm{sec}$. 1). The supervision of the minister competent for physical culture does not cover disciplinary and regulatory decisions of the authorities of Polish sports associations related to the course of sport competition (Act on Sport, Article 16 sec. 2). Nowakowska A Osiński Ł 2017 p. CIX, Wiktorowski D Ustawowa regulacja iproblemy praktyczne występujące przy nadzorze nad polskimi związkami sportowymi 2016 p. XXXVII. Organizational rules set by the Polish sports association are subject to review for compliance with legal regulations (Act on Sport, Article 16 sec. 3)

It should also be noted that in a sport in which competition is organized in the form of a league, the Polish sports association may form a professional league. If more than half of the sports clubs participating in the league competitions in the highest competition class in a given sport operate in the form of joint-stock companies, it is an obligation to create a professional league (Act on Sport, Article 15 sec. 1-2; Krześniak E 2016 passim habilitation thesis). The professional league in Poland is managed by a legal person (in the meaning of a body of persons or an entity considered as having many of attributes of a natural person and especially the capacity to sue and be sued) operating as a capital company. The rules of its functioning are set out in the agreement concluded between the Polish sports association and the league management company. The agreement should contain, in particular, provisions guaranteeing the implementation of the rights of the Polish sports association, including in the scope of establishing and implementing sports, organizational and disciplinary rules and its share in revenues related to the management of the professional league (Act on Sport, Article 15 sec. 4-5).

Since the $1^{\text {st }}$ May 2004 Poland has been a member state of the European Union there are cumulatively two legal systems in force within its territory. First, the community legal system, having priority of application. Second, the national legal system. The latter in the area of insolvency consists mainly of the $28^{\text {th }}$ February 2003 Bankruptcy Law Act defining the rules for the collective 
The need for change in the approach to insolvency of sport clubs...

satisfaction of creditors by liquidating the insolvent debtor's assets and the $15^{\text {th }}$ May 2015 Restructuring Law Act setting out the terms of the arrangement between the insolvent, or threatened by insolvency, debtor and the creditors.

Bankruptcy proceedings are civil proceedings generally consisting of two main segments. First, the proceedings for the declaration of bankruptcy, which is aimed at resolving the declaration of bankruptcy of the debtor. Proceedings are initiated at the request of the authorized entity, which is the debtor and each of his personal creditors. The court cannot start proceedings ex officio. After the bankruptcy is announced by the court, the proper bankruptcy proceedings begin. The date of issuing the bankruptcy order by the court is the date of bankruptcy. The ruling on the declaration of bankruptcy is effective and enforceable from the date of its issuance. When declaring the debtor's bankruptcy, the court appoints a judge-commissioner, who is in charge of the proceedings, and a trustee of the bankruptcy estate. The trustee covers the management of the debtor's assets and proceeds to the liquidation of these assets into cash. As a result of the declaration of the bankruptcy, the debtor's obligations become immediately payable, and nonmonetary liabilities are automatically converted into monetary liabilities ipso iure (by virtue of law). Non-performed synallagmatic contracts, based on a formula do ut des("I give you and you give me"), can be executed by the trustee but the trustee can withdraw from the contracts As a part of bankruptcy proceedings, the trustee establishes a list of claims. The trustee liquidates all the debtor's assets into cash. As a rule, the disposal of assets requires an estimation and takes place through an auction. The trustee divides the accumulated funds among the creditors within the so-called dividing proceedings with four categories of satisfaction. State Treasury receivables are treated equally with private receivables. Claims secured on the debtor's property in a material manner such as mortgages and pledges are subject to the so-called rights of separation. Secured creditors receive priority over other creditors and are given the sums obtained from the sale of the encumbered property.

Restructuring is carried out in the following four separate restructuring proceedings: (1) proceedings for the approval of the arrangement, (2) accelerated arrangement proceedings, (3) arrangement proceedings, and (4) sanation (recovery; "sanation" comes from the Latin word "sanatio") proceedings. The central concept of restructuring is concluding the arrangement. The arrangement includes personal claims arising prior to the opening of the restructuring proceedings, unless the Restructuring Law Act provides otherwise. A resolution of the creditors' meeting on acceptance of the arrangement shall be taken if the (a) personal majority of voting creditors (majority per capita), who have right of this important vote and (b) who represent at least two-thirds of the amount of debt due to the voting creditors, support the arrangement. 


\section{b) License for national and European competition}

The PZPN License System, including the granting of licenses, authorizing the licensee to participate in PZPN club competitions and UEFA club competitions, has, among other things, the following goals: "improving the economic and financial capabilities of clubs, increasing their transparency, credibility" and "protecting club creditors by ensuring that the club fulfills its obligations to players, coaches, employees, tax / social security institutions and other clubs "WZPN (Voivodeship Football Association), PZPN and UEFA" (Point 1.1. d, e of the License Guide).The License Guide focuses on protecting the interests of selected categories of creditors of the sports club. It should be indicated here that state law prohibits favoring creditors in the event of threat of debtor insolvency or bankruptcy. The indicated axiological foundations of the licensing system result in specific practical consequences. In case of bankruptcy of a football club PZPN shall terminate a license (in accordance with point 4.3.3. point $\mathrm{c}$, $\mathrm{d}$ of the License Guide). The regulation from the national federation is based on UEFA regulations

In accordance with the License Guide point 4.3.3.c, d, "the license shall terminate without prior notice upon the resolution on the liquidation of the licensee; upon the issuance of a court order against the licensee regarding bankruptcy; upon the issue of a court order against the licensee to change the arrangement bankruptcy to liquidation bankruptcy." The handbook refers to the structure of the arrangement of the bankruptcy, which came into effect $1^{\text {st }}$ January 2016 and does not refer to the institution of the present Restructuring Law. Whenever the License Guide mentions "arrangement bankruptcy", it should now be adapted to restructuring proceedings on an adaptation basis.

Pursuant to License Guidepoint 4.3.4, "The PZPN Club License Commission may suspend or revoke a license if a court order is announced against the licensee regarding bankruptcy with the option of entering into an arrangement." Similarly, such an effect should be attributed to the opening of the restructuring procedure (except for the procedure for approval of the arrangement). However, according to License Guide, point 4.3.6,

The PZPN Club Licenses Committee waives the suspension or withdrawal of licenses if the licensee goes bankrupt with the option of entering into an arrangement and the purpose of the club management or the administrator appointed by the court will be to save the club and its business activities, and the arrangement proposed by the club with creditors will not lead to a decrease in the nominal value of the club's obligations towards PZPN, Ekstra klasa SA, PZPN members, footballers, coaches and other members of the club's training staff and club employees. Such club will not be entitled to participate in UEFA Club Competitions. If the club is declared bankrupt with the option of 
The need for change in the approach to insolvency of sport clubs...

entering into an arrangement, the club is subject to the ex officio and automatically the control and supervision procedure set out in Chapter 5 of the PZPN License Guide.

Finally, according to License Guide, point 4.3.9.the given license is not transferable in any way to another entity.

\section{c) Specific problem under Polish law}

The content of league law regarding the insolvency of a sports club prompts some reflection. The following question arises. Can the Polish sports association validly stipulate in its league law that the declaration of bankruptcy of the sports club results in the loss of the right to participate in the games?

In accordance with Article 83 of Bankruptcy Law Act (hereafter referred to asB.L.) provisions stipulating that in the event of submission of a bankruptcy petition or in the event of a declaration of bankruptcy by court ruling, a change or termination of the legal relationship to which the party is bankrupt is null and void. Thus the provision of the contract reserving a change or termination of the legal relationship to which the party is a bankrupt is invalid in the event of: a) filing for bankruptcy or b) declaration of bankruptcy (Adamus 2019 Bankruptcy and Restructuring Law in Poland Societas et Iurisprudentia p. 24, Adamus R 2018 Grounds for opening restructuring proceedings in Poland p. 162 - 166). However, the provision of B.L. Article 83 refers to "contract terms". It was placed among the provisions regulating the impact of bankruptcy on the "obligations" of the bankrupt. In principle, except in the case of B.L. Article 86, these provisions apply either to contract law such as ineffectiveness, offsetting, interest withdrawal from the mutual contract, transformation of non-monetary liabilities into monetary, and immediate maturity, or to specific types of liabilities such as rent, lease, and order, in the context of bankruptcy. On the other hand, the License Guide clause on the termination of the license in the event of the bankruptcy of a sports club is not a contractual provision. Its specific legal nature has already been highlighted. Moreover, this clause refers to relations related to participation in the competition. Therefore, it is of a legal and organizational nature. It regulates the specific relation of participation in a specific sporting venture. In addition, a potential buyer of an enterprise of a bankrupt sports club or an organized part of such enterprise can individually obtain a license which is "not transferable". It could happen as a part of a prepared liquidation. Article 56a B.L. stipulates that an application for the declaration of bankruptcy may be accompanied by an application for approval of the terms of sale of the debtor's enterprise or its organized part or assets constituting a significant part of the enterprise. The court shall accept the application for approval of the terms of sale, if the price is higher than the amount that can be 
obtained in bankruptcy proceedings on liquidation under general rules, less the costs of proceedings that should be incurred in connection with liquidation in such mode. The court may accept the application if the price is close to the amount possible to obtain in bankruptcy proceedings on liquidation under general rules, reduced by the costs of proceedings that should be incurred in connection with liquidation in this mode, if there is an important public interest or the possibility of preserving the enterprise the debtor. Considering the application, the court in the decision on the declaration of bankruptcy approves the terms of sale, specifying at least the price and the buyer of the assets being the subject of the sale referred to in this chapter. In the order, the court may also refer to the terms of sale specified in the draft contract.

\section{d) General remarks}

De lege ferenda (as a postulate of changes in law), it seems that the License Guide should introduce a fast license qualification path, including the flexible design of the license promise, for the buyer of a bankrupt sports club enterprise.

The regulation of licensing rules for participation in league games should refer to the effects of opening restructuring proceedings. The maintenance of the license should be considered admissible subject to the conclusion by the sports club of a restructuring (non-liquidation) agreement or the submission of arrangement proposals which do not provide for any redemption for certain categories of interest (subject to the universal in civil law volentinon fitiniuria principle - wanting is not hurt).

\section{FINAL REMARKS}

In summary the following factors should be mentioned. Sport clubs operating as entrepreneurs in the free market economy are naturally exposed to the problem of insolvency. Insolvency is a common phenomenon. The link between a sports success and the amount of revenue of a sports club, revenues from broadcasting rights, payments from sponsors, and profits from merchandising, makes sports activities very risky. Football is not currently a match between equals. The winner is not just primus inter pares - first among equals. There is a phenomenon of monopolization of football activity. Inequalities in the distribution of football profits, rising spending on players' salaries, increasing transfer fees are also risk factors for insolvency. To avoid the risk of sports clubs becoming insolvent, sustainable, flexible and proportional limits on expenses for transfer fees and fees for players should be introduced. 
The need for change in the approach to insolvency of sport clubs...

Insolvency law is a state competence. Nevertheless, football organizations should introduce a more flexible approach. In the event of a threat of insolvency or in the event of the insolvency of a sports club, it is better to skillfully use the institutions of bankruptcy and restructuring law than to immediately exclude the club from the competition. Insolvency is a typical risk in the market game. It does not always have to be the result of intentional action or recklessness of the board. A club that exhibits threatening insolvency should be entitled to use the available restructuring procedures. Preventing financial problems at due time is with no doubt a win-win solution for club creditors and contractors. Harmful behavior is usually to refrain from such restructuring. The company which runs a football club is responsible for the obligations to the league authorities, the training staff, players but also to many other sorts of creditors not considered privileged according to UEFA regulations. Therefore, one cannot look at problems related to the club's insolvency only from the perspective of the league's interests. The common interest of all creditors is important. It should not be that, in the event of a threat of insolvency, the club refrains from the collective restructuring procedure for fear of losing its license. After all, the sooner financial problems begin to be solved, the better results can be achieved. If the club is ultimately insolvent, public law rules force management board to file for bankruptcy. In such cases, the fear of losing the license as a result of bankruptcy may lead to concealment of actual financial results; delays with submitting an application to the detriment of creditors. At the same time, bankruptcy and restructuring procedures are an invention of the legislator to deal with payment failure. If no bankruptcy or restructuring occurs in due time, there will be a very serious selective satisfaction of creditors to the detriment of the general public.Failure to file for bankruptcy or restructuring will not improve the situation of creditors.

If UEFA's goal is to ensure that only economically strong clubs can participate in the games:

a) in the face of financial difficulties (sometimes random, unpredictable and unforeseen), restructuring proceedings may help to avoid bankruptcy and to heal the financial situation; in such a case depriving the club of a license would be disproportionate and wasting the sporting potential sometimes built over generations,

b) bankruptcy proceedings may allow for an immediate exchange of the indebted club owner for a new investor with no financial problems, without the need to liquidate the club.

UEFA should not introduce a rule: commencing the procedure of protecting against creditors means losing the license. Rather, UEFA should introduce conditions on which the club should implement the procedure in connection with its insolvency in order not to lose its license. The approach to the 
problem of sports club insolvency should be carefully discussed and urgently redefined.

\section{REFERENCES}

Adamus, R. (2019) Bankruptcy and Restructuring Law in Poland, Societas et Iurisprudentia, vol. VII, issue 2, Trnava, Slovakia : p. $19-49$

Adamus, R. (2019) Niewypłacalność klubu piłkarskiego [Football club insolvency] Doradca Restrukturyzacyjny, No 4, p. 108 - 111

Adamus, R. (29.10.2019) Pieniądze na boisku nie grają, ale w sporcie wygrywa ten, kto je ma, [Money on the pitch does not play, but in sport the one who has it wins] Dziennik Zachodni p. 20

Adamus, R. (21 - 27.10.2019) Kopanie monet. Szalone zarobki piłkarzy [Kicking coins. Crazy earnings of footballers], Do Rzeczy No 43; p. 88 89

Adamus, R. (2018) Grounds for opening restructuring proceedings in Poland. Gaps in Russian Legislation, Moscow, No 7: p. 162 - 166

Adamus, R. (2019) Prawo restrukturyzacyjne. Komentarz [Restructuring Law. Commentary] Warsaw, C.H. BECK: passim

Adamus, R. (2019) Prawo upadłościowe. Komentarz [Bankruptcy Law. Commentary]. Warsaw, C.H. BECK : passim

Adamus, R. (9.7.2019) Piłkarze z Gliwic piszą nie tylko historię swojego klubu ale i miasta [Footballers from Gliwice write not only the history of their club but also of the city], Dziennik Zachodni: p. 20

Bołyń, M. (2016) Analiza przepisów dotyczących przyznawania licencji klubom Ekstra ligi Żużlowej [Analysis of regulations regarding the licensing of Ekstra Speedway clubs], Lex Sportiva No 2: p. IV

Blackshaw, I. S. (2017) International Sports Law: An Introductory Guide. Springer: p. 8

Chołub, A. (2015) Sądowa kontrola decyzji dyscyplinarnych władz polskiego związku sportowego [Judicial review of disciplinary decisions of the authorities of the Polish sports association], Lex Sportiva No 4: p. IV

Fornalik, J. Szczudlik, K. (2019) Upadłość klubów piłkarskich z perspektywy piłkarzy [Bankruptcy of football clubs from the perspective of footballers], in :Adamus R. Geromin M. Groele B. Miczek Z, (editors), Restrukturyzacja i upadłość przedsiębiorstw 2.1 [Restructuring and bankruptcy of enterprises 2.1], Warsaw, C.H.BECK: p. 47 - 54

Foster, K. (2006) Lex sportiva and lex ludica: the Court of Arbitration for Sport's Jurisprudence. Entertainment and sports Law Journal, http://go.warwick.ac.uk/eslj/issues/volume3/number2/foster.Accessed 12.12.2019

Gardiner, S. (2001) Sports Law, Cavendish: p. 7 
The need for change in the approach to insolvency of sport clubs...

Greenfield, S. Osborn, G. (2000) Law and Sport in Contemporary Society, Psychology Press: p. 5

Greenfield, S. Osborn, G. (2001) Regulating Football: Commodification, Consumption and the Law, Pluto Press : p. 14

James M (2013) Sports Law, Macmillan International Higher Education: p. 10

Kiełbasiński, W. Kosecki, M. (2015) Zasady finansowania klubów sportowych $\mathrm{z}$ budżetu jednostki samorządu terytorialnego [Financing rules for sports clubs from the budget of the local government unit], Lex Sportiva No 4: p. XL

Krześniak, E. (2016) Kluby i organizacje sportowe w prawie polskim na tle rozwiązań zagranicznych [Sports clubs and organizations in Polish law against the backdrop of foreign solutions], Warsaw, C.H. BECK: passim

Kulikowska, M. (2015) Prawo wyścigów konnych w Polsce -analiza aktualnej regulacji prawnej, [Horse racing law in Poland - analysis of current legal regulations] Lex Sportiva No 4 p: XXXII

Nowakowska, A. Osiński, Ł. (2017) Kontrola i nadzór nad polskim związkiem sportowym [Control and supervision over the Polish sports association], Lex Sportiva No $2:$ p. CIX

Osiński, Ł. (2017) Zarobki nie tylko z kontraktów, czyli o stypendiach sportowych [Earnings not only from contracts, i.e. about sports scholarships], Lex Sportiva No 10: p. XXIV

Podręcznik Licencyjny dla Klubów Ekstraklasy na sezon 2020/2021 i następne (2020) [License Guide for Ekstraklasa Clubs for the 2020/2021 season and next] https://www.pzpn.pl/public/system/files/site_content/635/2864-

Podr\%C4\%99cznik\%20Licencyjny\%20dla\%20klub\%C3\%B3w\%20Ekstr aklasy\%20na\%20sezon\%202019\%202020\%20i\%20nast\%C4\%99pne.pdf Accessed 12.12.2019

Siekmann, R.C.R. Soek, J. (2012) Lex Sportiva: What is Sports Law? Springer Science \& Business Media, p. 12

Siekmann, R.C.R. (2012) Introduction to International and European Sports Law: Capita Selecta, Springer Science \& Business Media: p. 12

UNCITRAL Legislative Guide on Insolvency Law, New York 2005, p. 15

Warchoł, M. (2015) Umowa sponsoringu w sporcie [Sponsorship agreement in sport]. Lex Sportiva No 1: p. IX

Widłak, T. (2015) Wybrane uwagi na temat charakteru i statusu lex sportiva w przestrzeni prawnomiędzynarodowej [Selected comments on the nature and status of lex sportiva in international law], Ruch Prawniczy Ekonomiczny i Społeczny, No 4: p. 81

Wiktorowski, D. (2015) [Trybunał Arbitrażowy ds. Sportu przy PKOL jako organ jurysdykcji w sprawach sportowych The Arbitration Tribunal for Sport at PKOL as a body of jurisdiction in sporting matters] Lex Sportiva, No 3: p. VIII 
Wiktorowski, D. (2015) Nowe przepisy licencyjne PZPN dla klubów Ekstraklasy [New PZPN licensing regulations for Ekstraklasa clubs]. Lex Sportiva No 1: p. IV

Wiktorowski, D. (2016) Ustawowa regulacja i problemy praktyczne występujące przy nadzorze nad polskimi związkami sportowymi, Statutory regulation and practical problems occurring during the supervision of Polish sports associations, Lex Sportiva, No 2 : p. XXXVII 